\title{
The relationship between the law and public policy: Is it a chi-square or normative shape for the policy makers?
}

\author{
Kiyoung Kim \\ College of Law, Chosun University, Kwang-ju, South Korea
}

Email address:

KiyoungKim@chosun.ac.kr

To cite this article:

Kiyoung Kim. The Relationship between the Law and Public Policy: Is it a Chi-Square or Normative Shape for the Policy Makers. Social Sciences. Vol. 3, No. 4, 2014, pp. 137-143. doi: 10.11648/j.ss.20140304.15

\begin{abstract}
Oftentimes we consider how the law and public policy were interwoven one anothor for any fine appeal to the constituents and global public. Nonetheless, we are fairly never definite to suggest any hard picture of their relationship. It rather involves an issue of meditative process of philosophy, humanity and social justice as well as a wider of public contention from the purview of temporal and spatial evolution. The paper, in the face with this difficult conundrum, attempts to highlight some of basics despite a surfeit of work products in this field. The paper begins with the instant queries or explanation from the peer scholar practitioners, which would be some of communication with the author. Then the author elicits some of principled relationship between the two concepts.
\end{abstract}

Keywords: Law and Public Policy, Administrative Law, Constitutionalism, Rule of Law, Social Justice, Public Agency, Administrative State

\section{Introduction: An Exchange for the Search of Law and Public Policy}

\subsection{From Shari Tewa/KJF Date: Tuesday, March 4, 2014 6:23:56 AM EST}

The relationship between law and public policy can be described as a 'hand in glove' one. Harrington and Carter (2009, p.27), described administrative law as the mechanism that controls governmental power given to administrative branches that "gives legitimacy and authority to state actions." It is important to note that there are four sets of laws that govern the behavior of administrators, regulatory, statutory, common and constitutional (Harrington, Carter, 2009, p.27). Regulatory law, as its name suggests, regulates how particular agencies operate focusing as Harrington, Carter (2009, p. 18) states on the procedural matters that arise out of non-compliance in areas of citizen complaints as in the case of Goldberg v. Kelly 397 U.S. 254 (1970) 6-3 where the court held that the district court was correct in its decision that procedural rules were followed to the letter and that due process was granted the litigants who were entitled to an oral hearing after termination of welfare benefits according to New York state law. (Harington, Carter, 2009, p. 39). Statutory law addresses social conditions and problems (Harrington, Carter, 2009, p. 27). These laws are created by state legislatures and the Congress that are designed to protect the citizens from injustices or unfairness such as monopoly on industries or creating of agencies such as FEMA (Federal Emergency Management Act) that may be traced back to 1803 in the first Congressional Act that legislatively provided assistance to a New Hampshire town devastated by fire (fema.gov), whose mission is to "support our citizens and first responders to ensure as a nation that we work together, to build, sustain and improve....and mitigate all hazards." (fema.gov) Statutes then for example, allow administrators to rescue those affected by natural disasters and to try to make them whole again. Constitutional Law can be termed the operating manual for the United States government. It also lays down the rules by which citizens must live in order to maintain an orderly society. It can also be said to be what gives rise to the "rule of law" that "everyone must follow the law." (uscis.gov) However the lion's share of Constitutional Authority goes to the Government and its distribution of powers, as in those that determine that the Congress has the power to coin money, the President being the Commander in chief of the military and powers not reserved by the Federal government will go to the states such as the maintaining of judicial branches that maintain law and order of the 
individual states. Under the Constitution's first amendment citizens have the right to engage in freedom of association and religion...(archives.gov). The common law aspect of administrative adjudication derives from the days of English rule when there were no laws written in books and matters were decided according to the wisdom (or in some cases lack of) the judges and attorneys who reasoned according to their own sense of fairness and justice and rendered their decisions accordingly. Thus stare decisis was born where the holding in one case whether the decision was fair or not, became the rule to go by in all other cases where the issues were similar (Harrington, Carter, 2009 p. 28). The holding in Goldberg v. Kelly 397 U.S. 254 (1970) 6-3 (Harrington, Carte, 2009, p. 41) illustrates this where "the reasonableness of the government's action" was at issue and that its secrecy created an unfairness to an individual who claims that their rights are being violated.

Then we have a question. Which branch of government serves the enforcement function? Is criminal punishment inherently a congressional power?

\subsection{Kiyoung Kim Date: Saturday, March 29, 2014 6:14:36 AM EDT}

Hi. Shari and Dr. Fandl,

Thank you for the question. I suppose it depends on how we connote the enforcement function. The legislature and judiciary would have their internal codes or regulations to administer their institutional mandate or needs. For example, the Court administrators or pertinent boards and commissions could set forth the salary scale or ethics standard. That could be the case within the legislature. Any more meaningful understanding of this concept would occur when the function is involved with the external actors or constituents. The interest and rights or loss and damage thereof as vested within the people or citizen would be the point of focus when we deal with the rules of law ideals or responsible public administration. In a limited exception, the interbranch controversies about the scope of enforcement authority may be disputed in the court proceedings, as in some countries of civil law tradition. The Courts often withdraw their engagement with the internal code or regulation since it would fall within the class of institutional autonomy and not be destined to the external actors or people. Then the enforcement function, in this narrow and normal sense, would be carried by the executive and judiciary. The Lockean concept of separation of powers principle would be sheer to endorse this perception that he did not recognize the judicial power as independent from the executive function. That could be seen otherwise in Montesquieu, who perhaps found a more deliberate procedure, adversary context of function or process, and the nature of power centered to identify and recognize a law than to execute it. While the society evolves, the distinctive understanding of two branches would come in a more depth that the judicial review of legislation or administrative rule is considered as one inviolable essence of democratic rule. The rise and higher progress of administrative state would make it starker between the two passive and one active branch.

The criminal policy and justice system would be a most antedated issue or policy area which drives us to think about, for example, the Hammurabi code in the Greek times. It would be a most sensitive issue that the feudal nobility and modern bourgeois exerted their every effort to safeguard from the arbitrary power of monarch or dictator. Some crucial elements historically proven any worst evil in the criminal justice system were inserted into the modern constitutionalism, for example, the cruel and unusual punishment in the Amendment IIXX, search and seizure, self-incrimination, right to confront the witnesses, jury trial and the like. Generally we may consider that the constitutional practice and principle of the civilized criminal justice system would endorse the legislative power as the founded authority to define the element of crime and punishment. That could be inferred or implied from the rule of law ideals, separation of powers principle, parliamentary system of government, intrinsic argument of state government, due process of law concept and so. Assuming if the judges or agencies formulate the criminal law, then it critically encroaches upon the nature and reason of humanity that the enforcers are the same as legislators. A self-law is one that the separation of powers principle would abhor. Respectfully.

\subsection{From: Deidre Hunter Date: Tuesday, March 4, 2014 7:40:36 AM EST}

The primary objective of public policy is to make and analyze governmental decisions. According to Harrington $\&$ Carter (2009) the four basic laws include the substantive and procedural rules the United States political system use to make legal rules. Therefore, public policy utilizes the four basic laws to help improve the public's problem, whether it is economical, social or political. For instance, in the media, there has been a lot of controversy over same sex marriage. Many people believe that prohibiting same sex marriages infringes on one of their constitutional rights, which has created a public problem and a call for a public policy. In some states, such as California, there have been laws put in place to allow same sex marriages in order to resolve the problem.

\subsubsection{Response: Kiyoung Kim Date: Thursday, March 6, 2014 9:33:21 PM EST}

Hello. Deidre.

You pointed very incisively at the most sensitive public issue. The same sex marriage reveals the wider context of constitutional, statutory and public policy issues. Importantly, the problem is structured with the constitutional review of statutes. This would be a firm practice over history that the Supreme Court can annul an unconstitutional statute although no express language so delegated the power to the judicial branch. This raises a concern about its anti-majoritarian difficulty against the 
majority rule. The latter is self-evident if we value a democratic understanding of national politics. The institution, in this sense, had been rooted in the distrust of politics. How much do you agree that the Supreme Court entertains a final say about the same sex marriage? If the local constituents largely abhor and dissent, is it acceptable that the SC sustain the validity of same sex marriage act?

Thank you for the communication. Respectfully.

\subsubsection{From Deidre Hunter}

Thanks Kiyoung! Personally, I think the Supreme Court decision plays a vital part in the laws and statues, new or old.

\subsection{From: Jessica Stanley Date: Thursday, March 6, 2014 10:01:42 PM EST}

Harrington and Carter (2009) describe administrative law as a process of making policies of fairness and accuracy by correcting administrative government. This type of law limits the authority of the administrative agencies and creates legitimacy to state actions (Harrington and Carter, 2009). Administrative law is the check and balance of governing agencies by setting boundaries to those who serve the public. In other words, administrative law "regulates the regulators" (Harrington and Carter, 2009, p. 26). Rulemaking is an important and time consuming process as it produces rules that are not always clear and understandable yet necessary. Kerwin and Furlong (2011) describes rulemaking as a refining principle that provides direction on many actions such as program implementation, procurement, conflict resolution, and personnel management. Rulemaking is a direct consequence of legislation proposed by the general public and enforced by governing agencies (Kerwin and Furlong, 2011).

Administrative law and rulemaking are necessary elements in public policy making. Public policies are public issues and concerns that are addressed by administrative agencies. These agencies, at any level, define the rules of operation that service the people. This rulemaking process is checked by administrative law for efficiency. For example, in my current profession as a license administrator for educational facilities, I witnessed several daycares being summoned to tribunals in the state of New York. These agencies serve the people and have their own processes and procedures. If inspected by the state or inclined to act because of several complaints, the administrative law will proceed with a rulemaking process on how the agency will continue to run in the future for safety, health, or environmental reasons. In conclusion, administrative law and rulemaking are distinct and vital roles in public policy making as it seeks to create and obtain effective policies for society.

\subsubsection{Response From Kiyoung}

\section{Hi. Jessica,}

Thank you for the informative commentary. You said of "fairness and accuracy" that the policy makers should respect to service the people. The terms would highlight the rule of law ideals. The concept of republic entails, by ways of struggle, reform and self-correction, the elements of democratic virtue that the governments are to be based and respect. A liberty and equality would come at front and the kind of proportionality principle needs to be ensured. The arbitrary public power certainly is an evil that the law and rule-makers have to avoid. You stated, "the agencies are inclined to act because of several complaints... the agencies began their rulemaking process for the future..." I am concerned, in that case, if they act equally between un-complained and complained facilities with same conditions. The concept of vested right or license interest would be one issue involved in the constitutional and administrative laws. I may ask if they take an impermissibly drastic measure against these concepts because they like to avoid a reprimand from the complaints? Respectfully.

\subsubsection{From Jessica}

\section{Hi. Kiyoung.}

Thank you for commenting on my discussion. You mentioned your fear that the agencies act equally between uncomplained and complained facilities. That is a fear of mine as well. From experience, some programs do just accept the low quality they are providing until administrative agenices reprimand their behavior. I think that is one of the powerful elements of administrative law is to correct the inappropriate and unproductive actions of programs that serve the public. With complaints being filed by parents in the daycares, for example, this lets your customers rate the company's product or service. This also allows administrative agencies to implement their corrective action which can come in the form of fines, provisional licences, and possibly shutting the low quality program.

Best,

Jessica

\subsection{From Michelle}

Hello Class,

Within the text Administrative Law and Politics, authors Harrington and Carter state that "administrative law seeks to reduce the tendency toward arbitrariness and unfairness in bureaucratic government (p. 2)." In short, this means that administrative law was created so that there would be some kind of checks and balance system for offering legal decisions. An example of this is seen in the fact that with administrative law, current cases can reference previous similar cases to provide a point of reference and render a similar decision. In rulemaking, rules are created to govern the people and this is done through the use of agencies. As defined in the text, "Rulemaking: How Government Agencies Write Law and Make Policy." rulemaking is the "direct consequence of the demands the American people make on the government (Kerwin \& Furlong, 2011)." In public policy making, administrative law and rulemaking serve as the foundational building blocks. Rulemaking ignites the notion that laws must be created and administrative adds to take, stating that laws can be formed 
for one area based on the formation of other similar laws. From here, public policy making can begin. These three items work simultaneously and jointly to further the progress of the American culture. Take for example the public policy agenda item of gun control. Gun control is an issue that the public is trying to contend with, currently. Past rulemaking has made certain actions with a gun illegal, including the murder or shooting of another. If one of the illegal actions with a gun occurs, administrative law can be used to determine the legal ramifications for that action. The three are heavily intertwined and rely heavily on one another.

\subsubsection{Response From: Kiyoung Kim Date: Saturday, March 8, 2014 2:50:21 AM EST}

Hello Michelle,

I agree that the rulemaking is a direct consequence from the demands of American people. I consider that the rules a bureaucracy establishes would take several forms in its function and operation. Some rules purely are addressed to the internal matter of departments, bureaus, units and branches as well as the House or Senate. They may include the internal steps reaching to the final decree of bureaus or House. Those could be made distinct from other nature of rules if they do not directly reach out to touch on the rights or interests of American people. Against this scope of rules, do you consider if the citizens could make a claim that the internal rules are arbitrary or unfair against the concept of democratic process or other principles? In the Korean context, the political parties are bound to ensure a democratic selection for the candidate of public election. In that sense, the rulemaking power of political party for the internal affairs would be controlled according to the constitution and relevant acts. Nonetheless, the Korean courts often refuse to review the constitutionality or legality of internal rule from the bureaucracy. Respectfully.

\subsubsection{From Michelle}

Hi Kiyoung.

Thank you for your response! I think that there should be some ways of creating uniformity amongst laws that way they are not arbitrary. I think that this is why Administrative law exists to create a uniform way of making decisions. And thank you for the information about the Korean process.

\section{A Synopsis on the Law and Public Policy}

We subsist under the law where we claim our rights and asked to be obliged to do something enforced. What is a law? The question would be perplexing in history, and one of crucial themes with many lawyers or legal philosophers. As we know, two most important perspectives had earned a universal and historical forge in academics, to say, the natural law and legal positivism. The concept of natural law deals in its primacy for the humanity and natural order which often can be traded as something inviolable or inalienable (Maritain, J. \& William S., 2001). The concept has strands in several aspects; (i) its anchor with the civil democratic revolution around 17 th and 18 th century (ii) its supremacy with the new constitutional states (iii) less quality as a realist law from ambiguities and lack of clear definition. For example, the sanctity of property right, freedom of contract, prohibition of ex post law, selfincrimination, and others may qualify for or originate from the natural law. The natural law theory provided the spirit and ground of US constitution, and generally had been considered to be entwined with the higher law concept, as in the case of Blackstone. The judicial review could be instituted on this philosophy or thoughts, but the Supreme Court in the Ex Parte McCardle repudiated the legal force of natural law in the real and concrete context of judicial business. However, it still is envisaged as idealistic and considered to be a prototype of justice in aspects of social intelligence. The legal positivists delve onto the basis of legal norms or their effect in the political community. In their case, they look most importantly at the state norms, hence, the political community often retracted, in concept, into a specific state or polity in order. The international community, in this purview, may lack a quality that the norms could be addressed in the coherence and system. However, the cosmopolitan concept of positivist theory, as we see in $R a z$, can bode prongs and intellectual consistence to explain the dynamism of international hard and soft laws. The legal positivists generally recourse the source of laws from the Grundnorm in the case of Kelsen or sovereign being as presumed by Austin. Hart's view and theoretical frame for the three phases of norms and ground for their legal effect are notable to penetrate most universally the current practice of laws in terms of the legal effect or source of law.

The concept of public policy may be related with the social justice, ethics and administration. It generally pursues a justice and desired state of public or community where the tension and conflict always exist between the ruling class and citizens (Harrington, C. B., \& Carter, L. H., 2009; Kerwin, C. M. \& Furlong, S.R., 2011; Scheingold, S.A., 2004). Historically, the public policy could be mightier to address the society than law where the benevolent Kings or Sovereigns liked to address both their needs and social justice. They may abrogate, more in endowment and divinity, the laws or social customs. The tension of public power and private interest could be one reason as well as offer a good dualism in understanding the rule of law concept and advent of modern democracy (2009; Federal Register Tutorial, 2014; Peter, K.E. (1989). In this dimension, the King would no longer be divine nor entitled to exercise a plenary power of state rule. Instead, the popular sovereignty in the US democracy or parliamentary one in the UK had been established to resolve a feudal conflict within the class and society. Lighted to be in vein of influence could arise the two contexts which are a contractarian view and plutocracy desire of the founding fathers. They underlay the mood and philosophical ethos of 
US revolution. Hence, three concepts as a pillar in private law were sanctified in the very foundation of US constitutional state, say, sanctity of property right, freedom of contract and due limits for the civil liability. The governmental power should be limited to protect the life and limb of citizens which addressed the Hobbes' evil, "war against all the rest." The due process concept was expressed as a fundamental principle of constitution where the human rights are inviolable and inalienable. The separation of powers principle could serve the freedom and wealth of new civil class in the continent, and bicameralism was devised for the check and balance within the federal congress. They see the role of judicial branch is important to preserve their civil interest.

\section{A Relationship between the Law and Public Policy}

From the summary, we can derive some assumptions between the law and public policy. First, a law plays to protect the private interest while the public policy pursues the social justice and mediates the competing interests, "private v. private" and "public v. private." The civil courts may address the first nature of conflict and the law of takings or regulatory laws may deal with the second aspect. Second, the public or administrative law may shape the legal plane of bureaucracy or public administration, and guarantee the rule of law ideals (2009). It plays as an enabling authority and, on the other, monitors an arbitrariness and unfairness in the bureaucratic government. In this context, the unresponsive and unfathomable bureaucracy in the Kafka's could be remedied. Third, for the welfare state in the late 19th and 20th century, a law can well be seen as one of authoritative expression of public policy to redress the evils of capitalist states. Some public laws, such as the Sherman Act classically and Lanham Act recently, may act to regulate the monopoly or oligopoly while other laws were enacted to restore the justice between the labor and employers.

A relationship involved with the two concepts could be analyzed in response to the four basic forms of law, covering the statutes, common law, constitution and regulatory laws. The statutes in the common law country are generally limited in scope and subject matters. However, the public laws share a similar extent against the civil law countries in terms of state intervention or public regulation. It comes as a good point of comparison that the common law countries have no general statute on the civil matters. The common law is specific to resolve a concrete conflict while the laws generally are abstract and designed to be implemented within the command of statute and discretion of bureaucrats. The public agency and administration may be subject to the judicial ruling which is an apparatus or system for the rule of law and considered as an essential component of liberal democracy (2009). The Chevron rule applies to respect the discretion of agency and the court often defers to the decision of agency unless the action or decree materially contravenes the provisions or undermines the intent of law-making authority. The Constitution is a supreme law of land and every level of public authorities are expected to be bound by it. The president and congress are not an exception. They act as an independent authority to interpret and execute the provisions and spirit of constitution (Federal Register Tutorial, 2014). The constitutional review often is conferred on the judicial branch in the normal or special line of judicial hierarchy depending on the national scheme of constitution. For example, the US and Japan manage a unitary structure in three or four tiers of appeal system. The constitutional review is commissioned to the normal nature of national Supreme Court. That can be compared with Germany, France and South Korea where we can find an independent highest court exclusively committed to the constitutional review.

The policy makers or administrators are expected to honor the Constitution and execute their constitutional responsibility faithfully in response with its command and desirability. With respect to the law and public policy, one important tendency in the recent age lies within the delegation of law-making authority to the Executive. The policy makers or administrators in the Executive are no longer an agency merely to implement the laws, but often delegated with the power to enact regulatory laws. This phenomenon had once been questioned to violate the constitutional provisions, which spell out three branches of government and their constitutional authority. The rule of "clarity and specificity" may operate to legitimate a legislative delegation

\section{The Role of Administrative Law and Rulemaking: A Comparative and Historical Sketch}

A relationship between the administrative law and rulemaking is symbiotic indeed, to structure the public lives of citizen as well as the politicians and bureaucrats. The administrative law could be broadly defined to encompass the statute, judge-made law and agency rule. In this purview, the administrative law epistemologically includes the rules of various nomenclature issued by the executive authorities, such as order, decree, rule, regulation and ordinance. In a narrow sense, perhaps more friendly to the intellectuals, the administrative law is designated as the statutes of Congress enacted in compliance with the constitutional and other statutory or internal requirements of the House and Senate. From this viewpoint, the two sources of law, say, the administrative law and rules, can be distinguished in terms of law-making authority, foundation of legal effect, scope and quality as a norm, and practical dynamism through the final addresses of norm or public policy (Federal Register Tutorial, 2011; Harrington, C. B. \& Carter, L. H., 2009). The administrative law springs from 
the congressional resolution, i.e., a political expression of public issues. In the US and general context of administrative law, the statutes in this scope had been limited and most typically had we been used to one statute, called APA, dealing with the nature of general procedural matters. The context would vary across the countries. For example, South Korea and perhaps a number of civil law countries are provided with the scope of general statutes, including the Administrative Litigation Act, Administrative Hearing Act on Cases and Controversies, Administrative Surrogate Enforcement Act or so forth. The titles of public law dealing with the specific public issues, such as the national economy, culture, public health and environment, had well been equipped. Often this relative abundance of public statute in these countries fuels a source of contention and disagreement in the international community about the trade liberalization. In comparison, we can note the trace of rules in history and through the contemporary government of US, which nowadays could rival the civil law countries in the number and scope about public intervention. This implies the substance of law and public policy now exist and is being enforced as less differently between both traditions of law despite their differences in formality. In this context, the roles of administrative law and rulemaking could be made distinct between two traditions.

The Administrative law took place more significantly in the civil law countries while the rulemaking of agencies would make practically more important in the US. There could exist many potentials of explicatory version about this subtlety. One reason might arise if the United States practices the federal system and its government operates within the stricture of three separated branches. Any obvious strength of rulemaking lies in its speed, efficacy with expertise and bureaucratic experience, compact procedure, non-political and subject- scale directness. The small and unitary system of government could fully exploit these advantages without any legal hurdle and encumbrance. This context may well be void under the federal system and cost the century long lessons of history for the US part. Take the example about the Department of Interior in the earlier years of rulemaking history (Kerwin, C. M. \& Furlong, S.R., 2011). It perhaps would be confused with the role of Home ministry in the UK which has a plenary power to regulate under the delegation of parliament. Actually with respect to the federal system and dual sovereignty between the federal and state government, the role of rulemaking could effectively be abridged to the limited scope and narrowed to its intrinsic role within the constitutional structure. This can be cast in other highlight about the foundation of federal union where the new wealthier class distrust with the strong government and less a regulation or intervention was preferred to protect their wealth and interests (Maritain, J. \& William S., 2001). The Brownlow Committee and FDR's response also showed this dilemma who described the chaos or un-system of policy makers in the New Deal era, with words "headless fourth branch (2011, p.11)." This would be a cost payable to redress any repercussion from the feudal or arbitrary rule in the earlier ages.

The concern arose and fermented to restore the social justice, while the integration and powers of national government had steadily expanded through the late of 20 century. We often call the 1970's era of public rulemaking as epochal. Almost all statutes enacted with the public programs delegated a rulemaking authority to the agencies (2011). The separation of powers principle once provoked a dispute concerning the legitimacy of legislative delegation, which turned to settle within the kind of important principles, for example, regularity and predictability as provided by the 1946 APA. This means that the rule of law ideals positively resolved to shake hands with the national cause toward the social justice. This speaks for the formality and system to deal with an entrenched contention between the private interests and social justice. It would be same in spirit as to the kind of benevolent capitalism, occasionally touched by the donations and contributions of Bill Gates or Warren Buffet, but could be made distinct in nature. From this, we can infer another aspect of role which would be substantial and econo-political. The role of administrative law and rulemaking underscores the legitimacy of public intervention into the private sector and for the social justice. The subject matter of these norms would encompass the production and consumers, which range across the regulation of monopoly or oligopoly, minimum wage, labor hours and standard, public health, environmental protection, commercial ads, misleading and unfair practices, price valorization, and so on.

\section{Their Roles: The Rule of Law and Modern Administrative State}

The role of Administrative law can be found in its paternal play for the rulemaking as we consider one APA provision, "[r]ule means the whole or part of an agency statement of general or particular applicability and future effect designed to implement, interpret, or prescribe law or policy" (2011). It grounds the plane that the agencies execute their powers and duties. As the Constitution binds, the president has the duty to faithfully execute the laws. A scope of constitutional powers other than this was prescribed in the Constitution. Nonetheless, the "execution of laws" clause would be one of traditional intrinsic historically and within the modern practice of constitutional state. Because of a strict hold with the separation of powers principle, the kind of "emergency power" was not incorporated within the US constitution although the presidency of US often had been attributed as a modern replacement of feudal King. This is in contrast with other modern presidential system of democracies, such as France and South Korea in the 1970's and 1980's. Even the Korean constitution enforced since 1987 spells out some of emergency power for the president to write the statutory laws as equal in status with the congressional act. This 
system have been absent in any expressive language and were deferred to the constitutional practice as we see in Youngstown involving the 1950 Korean wartime. In this light, we consider the execution of laws clause is fairly important in understanding the executive power within the US constitution. Then how could we define the laws enshrined in this provision? We may take an expansive view which includes the federal constitution, statutes, common laws and administrative rules. It does not outright reject an assumption that the president and agencies can make the rules necessary to carry their office. Consider also the federal supremacy clause. The assumption would attain if there is no definite statement in the Constitution about the hierarchy of norms among the forms of federal law. The controversies questioning the constitutionality of judicial review, though founded in Marbury v. Madison, arose in the same structure of logic and metaphor between the administrative statute and executive rules.

However, we may infer from our intuition and natural laws that the Constitution is supreme over other forms of federal law. Since the laws are the product of institution constitutionally created, they could not negate the mandate of constitution as a matter of nature. This logic can be applied to the relations between the APA and executive rules. The Congress was expressly conferred the power to legislate while the brother branch was described an authority for the execution of laws. They are co-equal and brothers from one father, namely the Constitution. I also take a view that the express intent of constitutional drafter should prevail that "no independent or contradictory rulemaking" is to be legitimately disabled. This means that the administration would be allowed amply, perhaps likely "bridegrooms in the sky," but that the administrative acts or illustratively the APA, will govern and enable a rulemaking. In hard nature at the least, it is true that the APA will command source of laws (agency), subject matter of rules (law and policy), scope of influence (implement, interpret, prescribe) (2011).

The roles of rulemaking in public policy making are enormous in the contemporary times. A historical survey informs the trend of rulemaking in its inception through the end of last century. As we see at the first page of Kerwin's, the society recently stirred about an AIG issue which implicates the public power over the civil arena (2011). A rulemaking defines a scope of specific issues which could make a profound effect on the lives of US citizen. They prescribe any more influentially the rights, benefits and services to be entitled to the American citizen. As C. Diver commented, it would be a "skin of living policy" if we can add for the statute, "cloak of skin" (2011). I am, however, reluctant to say this, if we are more concerned about such specific provision of rules than an abstract generalization of statutes. The bureaucrats certainly are an important player to address the social justice which should not be momentous. It should be living to adapt with the changing circumstances, but would be required of the extent of consistency, formality and generalizability. The rules decreed would be an expression of living policy under the cloak. Its role can be said to realize the distributive justice as Plato enlightened, which is specific and in accord with the social justice or equity.

\section{Acknowledgements}

This piece of article was produced during the exchange of weekly discussion in the Spring, 2014 at the Walden University. The scholar practitioners at Walden provided a great insight over the scope of law and public policy issues. Without their enthusiasm and participation in the discussion, it would be impossible to elevate our theme. Particularly, I have to thank my peers, Shari, Deidre, Jessica, Michelle, and Dr. Fandl, who contributed to the first part of this article.

\section{References}

[1] Harrington, C. B. \& Carter, L. H. (2009). Administrative law and politics: Cases and comments (4th ed.). Washington, DC: CQ Press

[2] Kerwin, C. M. \& Furlong, S.R., (2011). Rulemaking: How government agencies write law and make policy (4th ed.). Washington, DC: CQ Press

[3] Lavertu, Stephane, David Lewis and Donald P. Moynihan. (2013). Administrative Reform, Ideology, and Bureaucratic Effort: Performance Management in the Bush Era. Public Administration Review 73(6). 845-856

[4] Maritain, J. \& William S. (2001). Natural Law: Reflections On Theory \& Practice, Central South Bend. IN: St. Augustines Press (2001).

[5] Peter, K.E. (1989). The Rise of the entrepreneurial state: state and local economic development policy in the United States, Madison. WI: University of Wisconsin Press.

[6] Scheingold, S.A. (2004). The Politics of rights: lawyers, public policy, and political change, Ann Arbor. MI : University of Michigan Press.

[7] Federal Register Tutorial. Retrieved Mar. 2, 2014 from http://www.archives.gov/federal-register/tutorial/online-htm 1.html.

[8] About The Agency. Retrieved Mar. 2, 2014 from: http://www.fema.gov

[9] About the Bill of Rights. Retrieved Mar. 2, 2014 from: http://www.archives.gov

[10] About the Civics history and government questions for the naturalization test. Retrieved Mar. 2, 2014 from; http://www.uscic.gov. 